\title{
A novel cold-active $\beta$-D-galactosidase from the Paracoccus sp. 32d - gene cloning, purification and characterization
}

Anna Wierzbicka-Woś ${ }^{1 \dagger}$, Hubert Cieśliński ${ }^{2^{*}}$, Marta Wanarska² ${ }^{2}$ Katarzyna Kozłowska-Tylingo ${ }^{3}$, Piotr Hildebrandt ${ }^{2}$ and Józef Kur

\begin{abstract}
Background: $\beta$-D-Galactosidases (EC 3.2.1.23) catalyze the hydrolysis of terminal non-reducing $\beta$-D-galactose residues in $\beta$-D-galactosides. Cold-active $\beta$-D-galactosidases have recently become a focus of attention of researchers and dairy product manufactures owing to theirs ability to: (i) eliminate of lactose from refrigerated milk for people afflicted with lactose intolerance, (ii) convert lactose to glucose and galactose which increase the sweetness of milk and decreases its hydroscopicity, and (iii) eliminate lactose from dairy industry pollutants associated with environmental problems. Moreover, in contrast to commercially available mesophilic $\beta$-Dgalactosidase from Kluyveromyces lactis the cold-active counterparts could make it possible both to reduce the risk of mesophiles contamination and save energy during the industrial process connected with lactose hydrolysis.

Results: A genomic DNA library was constructed from soil bacterium Paracoccus sp. 32d. Through screening of the genomic DNA library on LB agar plates supplemented with X-Gal, a novel gene encoding a cold-active $\beta$-Dgalactosidase was isolated. The in silico analysis of the enzyme amino acid sequence revealed that the $\beta$-Dgalactosidase Paracoccus sp. 32d is a novel member of Glycoside Hydrolase Family 2. However, owing to the lack of a BGal_small_N domain, the domain characteristic for the LacZ enzymes of the GH2 family, it was decided to call the enzyme under study 'BgaL'. The bgaL gene was cloned and expressed in Escherichia coli using the pBAD Expression System. The purified recombinant BgaL consists of two identical subunits with a combined molecular weight of about $160 \mathrm{kDa}$. The BgaL was optimally active at $40^{\circ} \mathrm{C}$ and $\mathrm{pH} 7.5$. Moreover, BgaL was able to hydrolyze both lactose and o-nitrophenyl- $\beta$-D-galactopyranoside at $10^{\circ} \mathrm{C}$ with $K_{\mathrm{m}}$ values of 2.94 and $1.17 \mathrm{mM}$ and $k_{\text {cat }}$ values 43.23 and $71.81 \mathrm{~s}^{-1}$, respectively. One $U$ of the recombinant BgaL would thus be capable hydrolyzing about $97 \%$ of the lactose in $1 \mathrm{ml}$ of milk in $24 \mathrm{~h}$ at $10^{\circ} \mathrm{C}$.

Conclusions: A novel bgaL gene was isolated from Paracoccus sp. $32 \mathrm{~d}$ encoded a novel cold-active $\beta$-Dgalactosidase. An E. coli expression system has enabled efficient production of soluble form of BgaL Paracoccus sp. 32d. The amino acid sequence analysis of the BgaL enzyme revealed notable differences in comparison to the result of the amino acid sequences analysis of well-characterized cold-active $\beta$-D-galactosidases belonging to Glycoside Hydrolase Family 2. Finally, the enzymatic properties of Paracoccus sp. 32d $\beta$-D-galactosidase shows its potential for being applied to development of a new industrial biocatalyst for efficient lactose hydrolysis in milk.
\end{abstract}

Keywords: Cold-active $\beta$-D-galactosidase, Paracoccus sp. strain 32d, lactose hydrolysis, cold-adapted microorganisms

\footnotetext{
* Correspondence: hcieslin@pg.gda.pl

† Contributed equally

2Department of Microbiology, Gdańsk University of Technology, Narutowicza

11/12, 80-233 Gdańsk, Poland

Full list of author information is available at the end of the article
} 


\section{Background}

Cold-active enzymes found in cold-adapted organisms thriving in Earth's polar regions and other areas, where the mean annual temperature is below $5^{\circ} \mathrm{C}$, offer a potential for the development of new industrial applications. Employing cold-active enzymes in the food industry reduces the risk of contamination by mesophilic microorganisms, allowing inactivation of them at moderate temperatures and changes in the taste and nutritional values of the foodstuffs being produced to be avoided [1].

Cold-active $\beta$-D-galactosidases primarily can be used in dairy industry for the production of lactose free milk for people afflicted with lactose intolerance. Besides eliminating nutritional problem, the low temperature of lactose hydrolysis in milk with an optimum temperature at approximately $10^{\circ} \mathrm{C}$ offer some other important advantages: $(i)$ the lactose hydrolysis can run during shipping and storage of milk that shortening the entire production process (save energy), (ii) eliminating any mesophilic microflora contamination, and (iii) allow the formation of nonenzymatic browning products formed at higher temperatures to be avoided. On the other hand, there are also technological reasons for removing of lactose from milk. The lactose hydrolysis in milk decreases its hydroscopicity, as well as facilitating the suppression of lactose crystallization in sweet condensed milk and ice creams production processes. Furthermore, the enzymatic hydrolysis can be used to remove lactose from the whey generated in the cheese production process. The conversion of the lactose in whey to glucose and galactose, which are more fermentable sugars than lactose allow to reduces the water pollution related to the dairy industry [2].

In addition, cold-active $\beta$-D-galactosidases can be also used for the synthesis of oligosaccharides. Oligosaccharides are water soluble and mildly sweet in comparison with the commonly used mono- and disaccharides. Their relatively low sweetness is useful in food production where enhancement of other food flavors is desirable. Moreover, some oligosaccharides promote the proliferation of bifidobacteria in the colon, thus suppressing the growth of undesirable bacteria [3].

An ideal cold-active $\beta$-D-galactosidase for treating milk should work well at approximately $10^{\circ} \mathrm{C}$; be highly active at pH 6.7-6.8; not be inhibited by $\mathrm{Na}^{+}$and $\mathrm{Ca}^{2+}$ ions or galactose and glucose, and be specific for lactose. It is important to note that currently applied to lactose hydrolysis, the mesophilic Kluyveromyces lactis $\beta$-Dgalactosidase (e.g. commercially available Lactozym Novo Nordisk) has a temperature optimum of approximately $50^{\circ} \mathrm{C}$ and displays poor activity below $20^{\circ} \mathrm{C}$. Therefore, in recent years, a great deal of effort has been invested in the isolation and characterization of novel cold-active $\beta$-D-galactosidases from different sources. These have mainly been bacterial enzymes isolated from Arthrobacter sp. B7 [4-6], Arthrobacter sp. C2-2 [3], Arthrobacter sp. SB [7], Arthrobacter psychrolactophilus strain F2 [1,8], Arthrobacter sp. 32c [9], Arthrobacter sp. 20B [2], Flavobacterium sp. 4214 [10] Pseudoalteromonas sp. 22b [11-13], Pseudoalteromonas haloplanktis [14], Pseudoalteromonas sp. TAE 79b [15], Rahnella aquatilis 14-1 [16], Planococcus sp. SOS orange [17], Planococcus sp. L4 [18], and Carnobacterium piscicola strain BA [19]. In contrast the authors have found only a few reports of cold-active $\beta$-D-galactosidases isolated from other sources: yeast Guehomyces pullulans [20] and a soil metagenomic DNA library [21]. Hitherto, most of the cold-active $\beta$-D-galactosidases previously reported showed optimum temperature of activity at approximately $25-40^{\circ} \mathrm{C}$, and only LacZ Arthrobacter psychrolactophilus strain F2 revealed optimum temperature of activity at $10^{\circ} \mathrm{C}$. Generally, the most of above-mentioned cold-active $\beta$-D-galactosidases reveal high efficiency of the lactose hydrolysis in milk at low temperature, however, to the best of our knowledge, none of them is used as industrial biocatalyst so far.

Our previous studies on cold-active $\beta$-D-galactosidases isolated from Pseudoalteromonas sp. 22b [11-13] and Arthrobacter sp. 20B [2] revealed the factors that limit their usefulness as biocatalysts for industrial lactose hydrolysis in milk. These factors are, first, the insufficient efficiency of the production recombinant form of the cold-active LacZ Pseudoalteromonas sp. 22b $\beta$-Dgalactosidase in E. coli expression system [12]. Secondly, the LacZ Arthrobacter sp. 20B [2] revealed the low stability of purified enzyme, that is the major disadvantage of using this cold-active $\beta$-D-galactosidase as biocatalyst, owing to the problems with providing the proper conditions for long storage of this enzyme.

The present study was conducted in order to carry out the molecular and enzymatic characterization of the cold-active recombinant $\beta$-D-galactosidase of Paracoccus sp. 32d. What is especially important, the active form of the recombinant enzyme was effectively produced by means of the E. coli expression system and the purified enzyme was stable and showed a high efficiency of lactose hydrolysis in milk. Moreover, to the best of the author's knowledge, this is the first report on characterization of $\beta$-D-galactosidase isolated from genus Paracoccus.

\section{Results}

\section{Characterization and identification of the strain 32d}

Strain 32d was Gram-negative, aerobic, non motile and rod-shaped. On LAS agar, this strain formed small, 
round, smooth, dark orange colonies with a diameter of 1-2 $\mathrm{mm}$. The optimal growth temperature was $20^{\circ} \mathrm{C}$ and growth was very poor below $5^{\circ} \mathrm{C}$ and above $30^{\circ} \mathrm{C}$. In contrast to $\beta$-D-galactosidase activity, lipase/esterase, amylase and protease activities were absent. Glucose, galactose and lactose were utilized.

An alignment of the $16 \mathrm{~S}$ rDNA gene sequence of the isolate 32d (GenBank, accession number GU111730.1) with the appropriate sequences available in the Ribosomal Database Project and the GenBank database, demonstrated that the isolate $32 \mathrm{~d}$ should be classified as a Paracoccus sp. (Figure 1) and that its closest relative is Paracoccus marcusii (99\% identity, 97\% query coverage).

\section{Cloning the $\beta_{-}-$-galactosidase gene from Paracoccus sp. $32 \mathrm{~d}$ and analysis of its nucleotide sequence}

The Paracoccus sp. 32d genomic DNA library was prepared in E. coli LMG194 and screened for the colonies that exhibited $\beta$-D-galactosidase activity. Finally, two positive transformants were selected as blue colonies on plates containing X-Gal (a chromogenic substrate for $\beta$ D-galactosidase). Both transformants were carrying the same recombinant plasmid with a BglII/SalI-cleaved genomic DNA fragment of nearly $5.5 \mathrm{~kb}$. Subsequently,

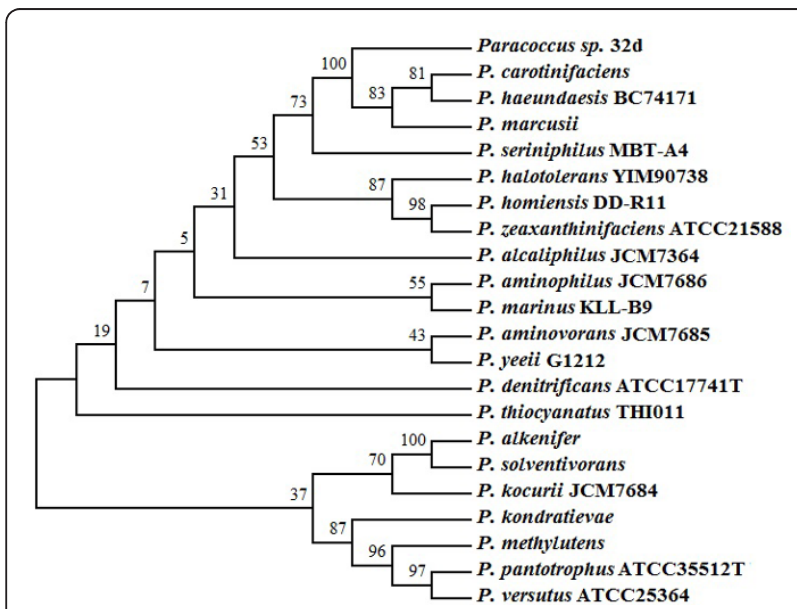

Figure 1 Phylogenetic tree based on a neighbor-joining analysis of the 16S rDNA gene of strain $32 \mathrm{~d}$ and closely related Paracoccus species Gene sequences from the following organisms were used (the numbers in parentheses are the GenBank accession numbers): P. alcaliphilus JCM7364 (D32238), P. alkenifer (Y13827), P. aminophilus JCM7686 (D32239), P. aminovorans JCM7685 (D32240), P. carotinifaciens (AB006899), P. denitrificans ATCC17741T (Y16927), P. haeundaesis BC74171 (AY189743), P. halotolerans YIM90738 (DQ923133), P. homiensis DD-R11 (DQ342239), P. kocurii JCM7684 (D32241), P. kondratievae (AF250332), P. marcusii (Y12703), P. marinus KLL-B9 (AB185959), P. methylutens (AF250334), P. pantotrophus ATCC35512T (Y16933), P. seriniphilus MBT-A4 (AJ428275), P. solventivorans (Y13826), P. thiocyanatus THI011 (D32242), P. versutus ATCC25364 (Y16932), P. yeeii G1212 (AY014173), and P. zeaxanthinifaciens ATCC21588 (AF461158). Bootstrap 1000. one of these recombinant plasmids (pBAD/ins $\beta 1$ ) was selected for further study. Sequence data from the $\mathrm{pBAD} / \mathrm{ins} \beta 1$ insert revealed an open reading frame of 2,193 bp encoding protein, which shares an average homology (63\%) with a $\beta$-D-galactosidase from Sinorhizobium fredii NGR234 (NCBI Accession No. ACP21732). The $\beta$-D-galactosidase encoded the ORF under analysis contained 731 amino acids residues, giving a calculated molecular weight of $81,750.4 \mathrm{Da}$ and a theoretical pI of 5.28 (ProtParam; ExPASy Proteomics Server).

The primary structure of Paracoccus sp. $32 \mathrm{~d} \beta^{-} \mathrm{D}^{-}$ galactosidase

A computer analysis of the amino acid sequence deduced for Paracoccus sp. 32d $\beta$-D-galactosidase, conducted using the InterProScan program http://www.ebi. ac.uk/Tools/InterProScan/ showed that it consisted of a carbohydrate-binding domain (1-151 aa residues), a immunoglobulin-like $\beta$-sandwich/ $\beta$-D-galactosidase/glucuronidase domain (153-243 aa residues), and a single catalytic domain (245-528 aa residues). Moreover, this comparison revealed the lack of Bgal_small_N domain at the C-terminus of Paracoccus sp. $32 \mathrm{~d} \beta$-D-galactosidase, a domain characteristic of LacZ enzymes (Figure 2). On the basis of sequence comparisons carried out by means of homology and hydrophobic cluster analysis [22], the enzyme from Paracoccus sp. 32d was classified into the Glycoside Hydrolase Family 2 which comprises the well-characterized LacZ $\beta$-D-galactosidases, such as E. coli LacZ $\beta$-D-galactosidase. However, the comparison of Paracoccus sp. 32d $\beta$-D-galactosidase sequence with cold-active LacZ $\beta$-D-galactosidases and $E$. coli Lac $Z$ enzyme sequences revealed a slight sequence homology in the vicinity of the catalytic glutamic acid residue present in the putative Acid/Base sites of LacZ enzymes (Figure 3A). Moreover, the comparison failed to find any homology with the consensus nucleophilic region of the LacZ enzymes (Figure 3B).

\section{Expression and purification of Paracoccus sp. $32 \mathrm{~d} \beta_{-{ }^{-}}^{-}$ galactosidase}

The arabinose-inducible promoter of the pBAD-MycHis A plasmid was used for the expression of the Paracoccus sp. 32d $\beta$-D-galactosidase gene in $E$. coli LMG194 cells. The highest enzyme production yields were achieved by adding L-arabinose to a final concentration of $0.2 \% \mathrm{w} / \mathrm{v}$, at $\mathrm{A}_{600} 0.5-0.55$ and by further cultivation for $8 \mathrm{~h}$ at $30^{\circ} \mathrm{C}$. The enzyme was purified by using the two-step procedure, presented in Table 1. Following this procedure, the enzyme was $\sim 96 \%$ pure (densitometric analysis; software ImageJ $\mathrm{v} 1.44 \mathrm{I})$ as determined by SDS-PAGE (Figure 4) and had an estimated apparent molecular mass of $80 \mathrm{kDa}$ 

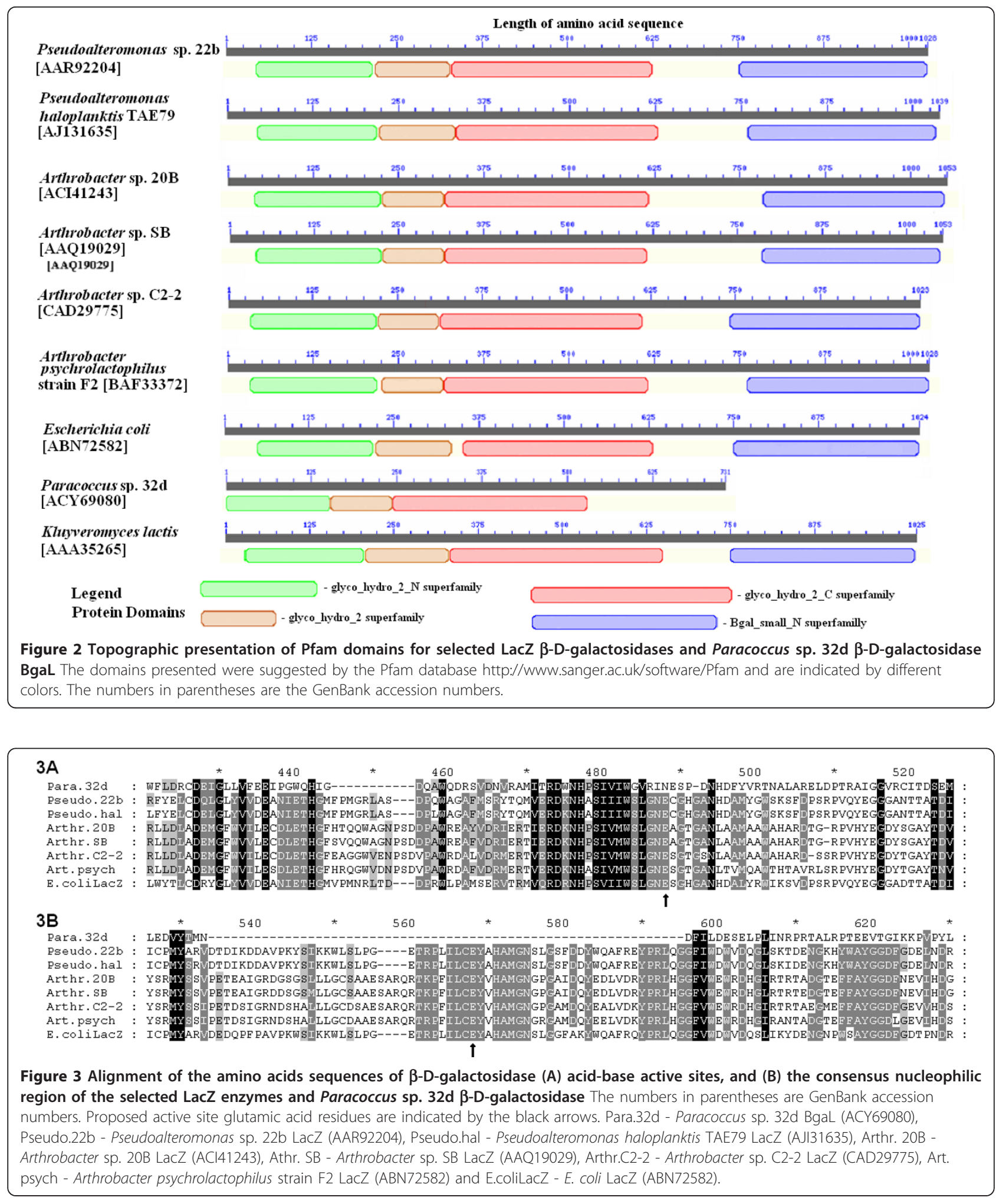

Table 1 Purification of recombinant Paracoccus sp. 32d $\beta$-D-galactosidase

\begin{tabular}{cccccc}
\hline Purification step & Total protein $(\mathbf{m g})$ & Total activity $(\mathbf{U})$ & Specific activity $(\mathbf{U} / \mathbf{m g})$ & Purification fold & Yield $(\%)$ \\
\hline Cell extract & 266.1 & 6213 & 23.35 & 1.0 & 100 \\
Fractogel EMD DEAE & 152.6 & 6053 & 39.67 & 1.7 & 97 \\
ResourceQ & 105.6 & 4328 & 40.98 & 1.8 & 72 \\
\hline
\end{tabular}




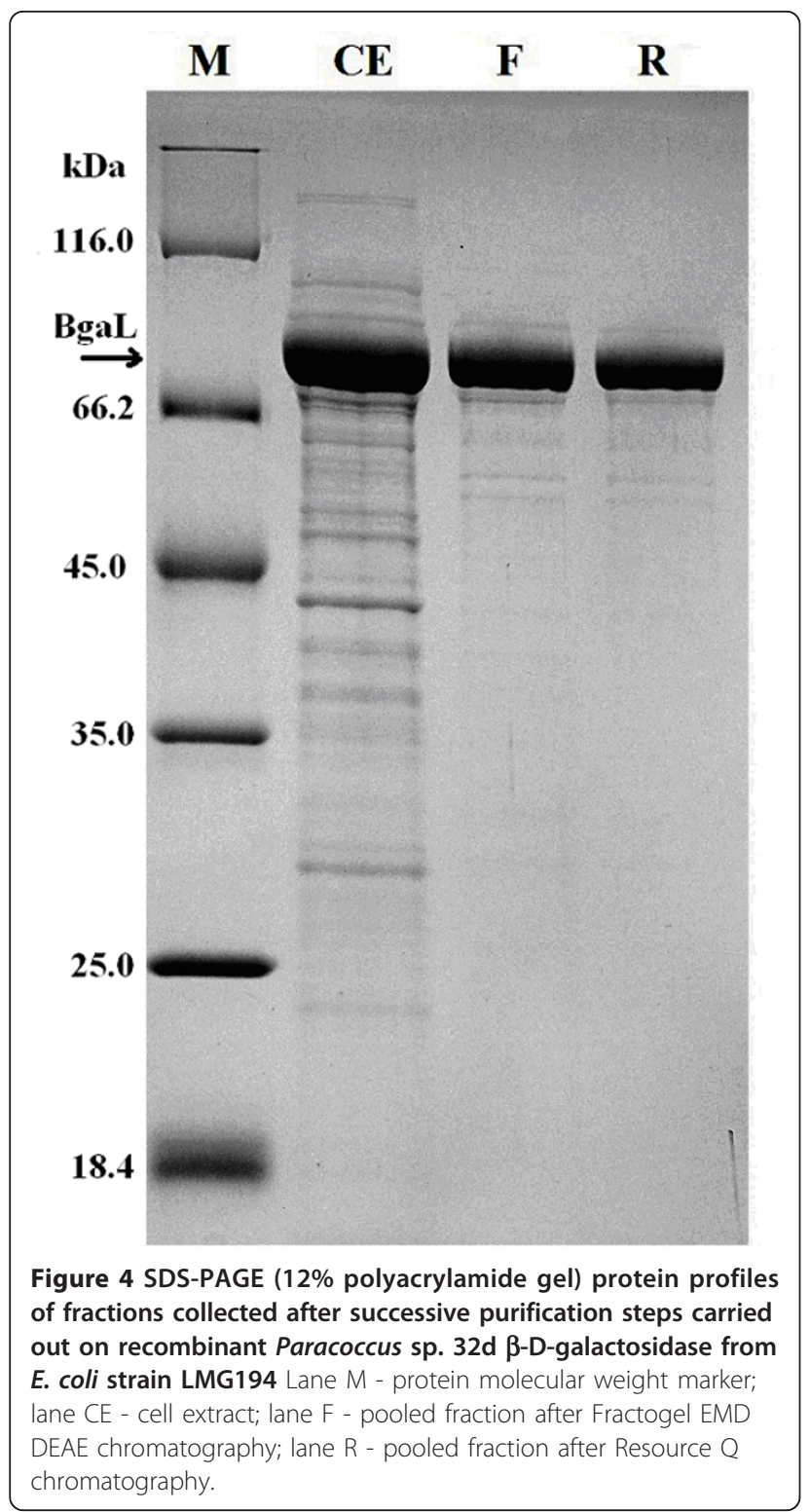

corresponding to the expected molecular mass calculated from the BgaL amino acid sequence. The relative molecular mass of recombinant BgaL, which was determined by gel filtration was $161 \mathrm{kDa}$ suggesting that the Paracoccus sp. $32 \mathrm{~d} \beta$-D-galactosidase is a dimer protein.

Finally, the purified enzyme was divided into two aliquots. One of the aliquots was dialyzed against a Tris$\mathrm{HCl}$ buffer $(20 \mathrm{mM}, \mathrm{pH} 7.3)$ and then used for protein crystallization experiments (data not shown).

What it is important to note is that, the activity of the purified $\beta$-D-galactosidase was depended on the buffer used to purify or store the enzyme. We compared the enzymatic activity of BgaL against $o$-nitrophenyl- $\beta$-Dgalactopyranoside as a substrate in a sodium phosphate buffer $(20 \mathrm{mM}, \mathrm{pH} 7.3)$ and the Tris- $\mathrm{HCl}$ buffer $(20$
$\mathrm{mM}, \mathrm{pH}$ 7.3), respectively. The Paracoccus sp. $32 \mathrm{~d} \beta$-Dgalactosidase revealed significantly higher activity in the sodium phosphate buffer than in the Tris- $\mathrm{HCl}$ buffer. The relative activity of $\beta$-D-galactosidase in the Tris$\mathrm{HCl}$ buffer was only $57 \%$ of the maximum enzymatic activity of BgaL in sodium phosphate buffer, respectively. Thus, we decided to characterize the enzymatic properties of BgaL with using the sodium phosphate buffer.

On the other hand the results presented in Table 1 reveal that the second purification step had a low efficiency. Moreover, the densitometric analysis of SDSPAGE gel stained with Coomassie Brilliant blue (Figure 4) revealed that the BgaL enzyme was $~ 93 \%$ pure after the first purification step. Therefore, the one step purification procedure of BgaL is the rationale way to reduce the cost of BgaL purification on large scale, important for the production of the enzyme for industrial applications.

\section{Properties of Paracoccus sp. $32 \mathrm{~d} \beta{ }_{-}{ }^{-}$-galactosidase}

A study of the substrate specificity of purified Paracoccus sp. $32 \mathrm{~d}$ enzyme was performed by comparing its enzymatic activity against the $o$-nitrophenyl- $\beta$-D-galactopyranoside (ONPG) and a variety of $p$-nitrophenyl (PNP)- $\beta$-glycoside substrates, respectively (Table 2 ). The Paracoccus sp. $32 \mathrm{~d}$ enzyme revealed enzymatic activities specific to the $\beta$-D-galactosidase. The highest activity was found with lactose analogs ONPG. The activity with $p$-nitrophenyl- $\beta$-D-galactopyranoside and $p$-nitrophenyl$\beta$-D-fucopyranoside as substrates were only $62 \%$ and $39 \%$ of that found with ONPG, respectively.

The thermodependency of the Paracoccus sp. $32 \mathrm{~d} \beta$ $D$-galactosidase activity was determined by assaying the enzyme activity at various temperatures from 0 to $70^{\circ} \mathrm{C}$ using ONPG as a substrate. The maximum activity enzyme shows at a temperature of $40^{\circ} \mathrm{C}$ (Figure 5). After

Table 2 Relative activity of purified Paracoccus sp. 32d $\beta$ D-galactosidase with various nitrophenyl-derived chromogenic substrates

\begin{tabular}{lc}
\hline Substrate & Relative activity (\%) \\
\hline o-nitrophenyl- $\beta$-D-galactopyranoside & 100 \\
$p$-nitrophenyl- $\beta$-D-galactopyranoside & 62 \\
$p$-nitrophenyl- $\beta$-D-fucopyranoside & 39 \\
$p$-nitrophenyl- $\beta$-D-galacturonide & 1 \\
$p$-nitrophenyl- $\beta$-D-glucopyranoside & $<0.01$ \\
$p$-nitrophenyl- $\beta$-L-arabinopyranoside & $<0.01$ \\
$p$-nitrophenyl- $\beta$-D-cellobioside & $<0.01$ \\
$p$-nitrophenyl- $\beta$-D-xylopyranoside & $<0.01$ \\
$p$-nitrophenyl- $\beta$-D-mannopyranoside & $<0.01$ \\
$p$-nitrophenyl- $\beta$-D-glucuronide & $<0.01$ \\
$p$-nitrophenyl- $\alpha$-D-galactopyranoside & $<0.01$ \\
\hline
\end{tabular}


$2 \mathrm{~h}$ incubation, the enzyme was thermostable at $30^{\circ} \mathrm{C}$ and below. However, the incubation at $50^{\circ} \mathrm{C}$ caused a rapid decrease of activity after $15 \mathrm{~min}$ incubation (Figure 6).

The Paracoccus sp. 32d $\beta$-D-galactosidase revealed maximum activity at $\mathrm{pH} 7.5$ and demonstrated above $80 \%$ of the maximum activity at a range of $\mathrm{pH}$ 6.0-8.0 (Figure 7). The enzyme was stable at $\mathrm{pH} 6.0$ and 7.0 ( $~ 90 \%$ of maximum activity) after $2 \mathrm{~h}$ incubation, but it rapidly lost activity at $\mathrm{pH} 4.0$ after $15 \mathrm{~min}$ incubation (Figure 8).

As shown in Table 3 the activity of the enzyme against ONPG as a substrate was slightly enhanced by K ${ }^{+}$ions and 2-mercaptoetanol and was unaffected by EDTA. It was slightly inhibited by $\mathrm{Mg}^{2+}$ ions, dithiothreitol and urea, respectively and was also partially inhibited by $\mathrm{Ca}^{2+}, \mathrm{Mn}^{2+}, \mathrm{Ni}^{2+}, \mathrm{Co}^{2+}$ ions and strongly inhibited by oxidized form of glutathione (GSSG). The strong inhibition effect of GSSG and the positive effect of 2-mercaptoetanol on the BgaL activity suggest the importance of Cys residues in this protein sequence. The Cys residues are uninvolved in the general mechanism of catalysis by $\beta$-D-galactosidases of the LacZ family [23]. However, the S-thiolation or oxidation of sulfhydryl group of some cysteine residues can lead to the conformational changes of BgaL that decrease its activity. The enzyme activity was also inhibited by glucose and galactose, the products of lactose hydrolysis. As shown in Table 4 the enzyme activity inhibition increases with increasing sugars concentrations and the glucose is a stronger inhibitor than galactose. On the other hand, $1 \mathrm{U}$ of the enzyme was able to hydrolyze about $97 \%$ and $91 \%$ of the lactose in $1 \mathrm{ml}$ of milk at $10^{\circ}$ $\mathrm{C}$ in $24 \mathrm{~h}$ and $11 \mathrm{~h}$, respectively (Figure 9 ).

A lyophilized enzyme was stable for at least a year when it was stored desiccated at $-20^{\circ} \mathrm{C}$. The reconstituted enzyme $(20 \mathrm{mM}$ sodium phosphate buffer, $\mathrm{pH}$ 7.3) was effective in hydrolysis of ONPG $(95 \pm 2 \%$ of

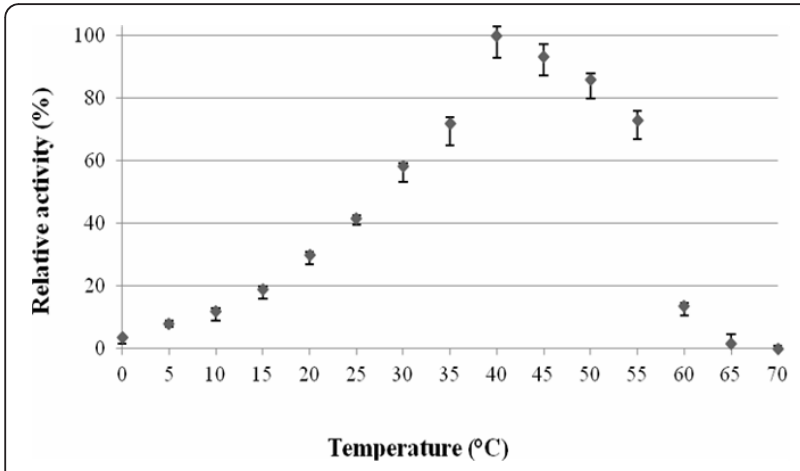

Figure 5 The effect of temperature on the recombinant Paracoccus sp. 32d $\beta$-D-galactosidase activity.

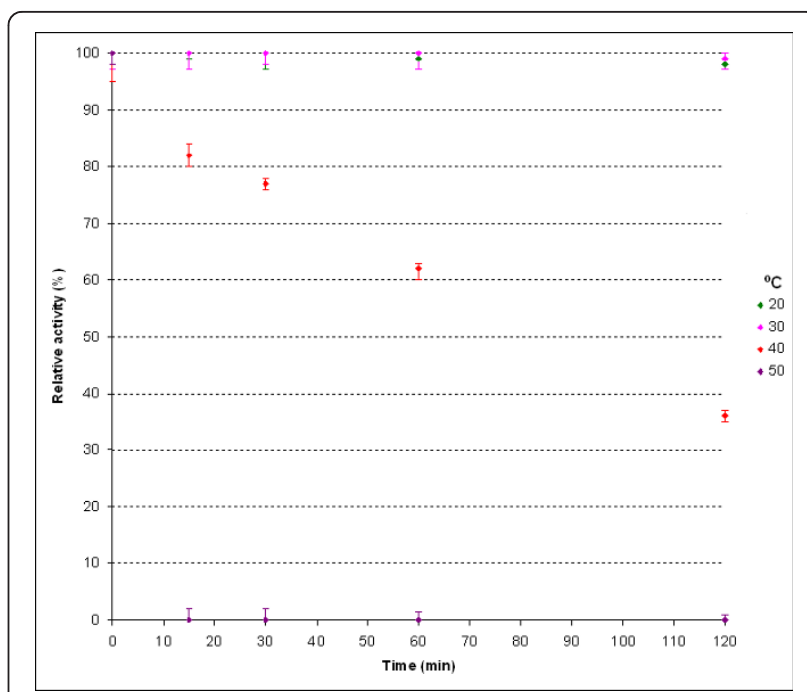

Figure 6 The effect of temperature on the recombinant Paracoccus sp. 32d $\beta$-D-galactosidase stability.

the starting enzymatic activity) or lactose $(93 \pm 2 \%$ of the starting enzymatic activity) at $20^{\circ} \mathrm{C}$.

A freshly purified enzyme was used to determine the $K_{\mathrm{m}}, k_{\text {cat }}$ and $k_{\text {cat }} / K_{\mathrm{m}}$ values at 10,20 and $30^{\circ} \mathrm{C}$ with ONPG and lactose as substrates, respectively. As shown in Table 5, the apparent $K_{\mathrm{m}}$ values for lactose increase at temperatures higher and lower than $20^{\circ} \mathrm{C}$. As a result, the enzyme's efficiency $\left(k_{\text {cat }} / K_{\mathrm{m}}\right.$ ratio $)$ for lactose is markedly affected at these temperatures, whereas this ratio is about two or four times higher at $20^{\circ} \mathrm{C}$. On the other hand, the apparent $K_{\mathrm{m}}$ values for ONPG are comparable at 10,20 and $30^{\circ} \mathrm{C}$, and adequate $k_{\text {cat }} / K_{\mathrm{m}}$ ratios increase constantly with an increasing temperature.

\section{Discussion}

A novel $\beta$-D-galactosidase gene from Paracoccus sp. 32d was cloned from a genomic DNA library by means of functional screening on $\beta$-D-galactosidase indicator plates. A BglII/SalI genomic DNA fragment bearing the $\beta$-D-galactosidase gene was sequenced, and an ORF

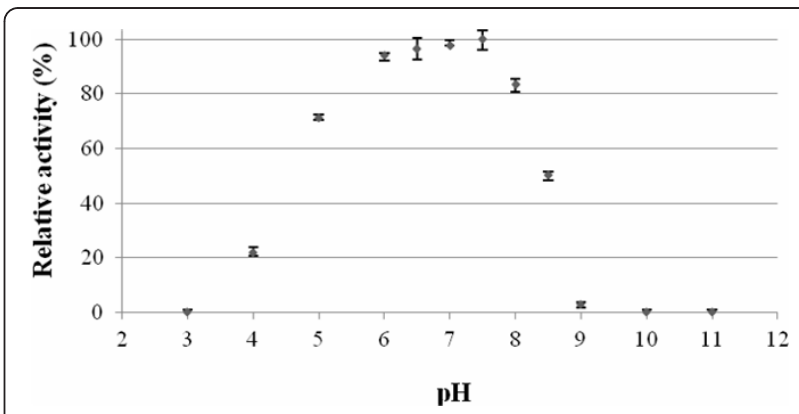

Figure 7 The effect of $\mathrm{pH}$ on the recombinant Paracoccus sp. 32d $\beta$-D-galactosidase activity. 


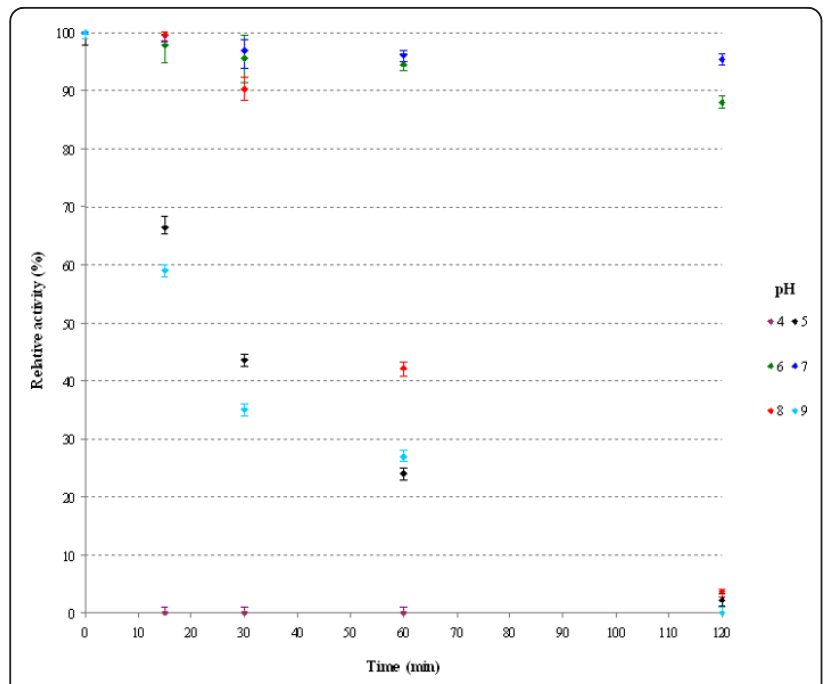

Figure 8 The effect of $\mathrm{pH}$ on the recombinant Paracoccus sp. 32d $\beta$-D-galactosidase stability.

encoding the $\beta$-D-galactosidase was found. Computer analysis of the BgaL amino acid sequence established that the Paracoccus sp. 32d enzyme belongs to Glycoside Hydrolase Family 2 (GH2). However, in contrast to other cold adapted $\beta$-D-galactosidases belonging to the GH2 family, the Paracoccus sp. 32d $\beta$-D-galactosidase possesses an acid-base active site slight similar to that typical of the LacZ family of $\beta$-D-galactosidase. However, it does not share the conserved nucleophilic site involved in catalysis that is typically found in this family of enzymes. Similar results for the same analysis were described by Gutshall et al. [5] for cold-active $\beta$-Dgalactosidase, designated isozyme 12, and isolated from psychrotrophic Arthrobacter strain B7. However, what is important to note is that the sequence analysis of isozyme 12 revealed that this enzyme belongs to Glycoside Hydrolase Family 42.

Table 3 The effect of metal ions and selected reagents on Paracoccus sp. 32d $\beta$-D-galactosidase activity

\begin{tabular}{lc}
\hline Ions/Reagents (10 $\mathbf{~ m M )}$ & Residual activity (\%) \\
\hline None & 100 \\
$\mathrm{~K}^{+}$ & 106 \\
$\mathrm{Mg}^{2+}$ & 97 \\
$\mathrm{Ca}^{2+}$ & 70 \\
$\mathrm{Mn}^{2+}$ & 75 \\
$\mathrm{Ni}^{2+}$ & 61 \\
$\mathrm{Co}^{2+}$ & 81 \\
EDTA & 100 \\
DTT & 93 \\
Glutathione oxidised & 30 \\
2-mercaptoethanol & 107 \\
Urea & 98 \\
\hline
\end{tabular}

Table 4 The effect of glucose and galactose on the recombinant Paracoccus sp. 32d $\beta$-D-galactosidase activity

\begin{tabular}{ccc}
\hline Sugar concentration (mM) & \multicolumn{2}{c}{ Relative activity (\%) } \\
& Glucose & Galactose \\
\hline 0 & $100 \pm 1$ & $100 \pm 2$ \\
20 & $75 \pm 1$ & $83 \pm 2$ \\
50 & $56 \pm 1$ & $67 \pm 1$ \\
100 & $38 \pm 2$ & $52 \pm 1$ \\
150 & $29 \pm 1$ & $39 \pm 2$ \\
\hline
\end{tabular}

Moreover, to the best of the authors' knowledge, the Paracoccus sp. $32 \mathrm{~d}$ enzyme is the first dimeric coldactive $\beta$-D-galactosidase determined as belonging to the GH2 family. Hitherto, the cold-active $\beta$-D-galactosidases characterized and belonging to that family are tetrameric enzymes $[2,3,7,11,14,15]$. What is interesting to note is that, in size the Paracoccus sp. $32 \mathrm{~d} \beta$-D-galactosidase subunit $(\sim 80 \mathrm{kDa})$ is clearly smaller than the subunit sizes typical of the LacZ family of cold-active $\beta$-Dgalactosidase, such as, for example, LacZ Pseudoalteromonas sp. 22b ( 115 kDa) [11] or LacZ Arthrobacter sp. 20B ( 116 kDa) [2]. The difference in size is caused by the lack of a BGal_small_N domain at the C-terminus of Paracoccus sp. 32d $\beta$-D-galactosidase (Figure 2). The BGal_small_N domain (pfam02929) is commonly found in $\beta$-D-galactosidases (Conserved Domains Database, NCBI). The catalytic and other domains typically found in LacZ enzymes are present in BgaL enzyme (Figure 2). The lack of the BGal_small_N domain make the Paracoccus sp. $32 \mathrm{~d} \beta$-D-galactosidase one of the smallest cold-active $\beta$-D-galactosidases (161 kDa, homodimer) to have been described to date. In comparison, the relative low molecular mass of native cold-active $\beta$-D-galactosidases have been reported for isozyme 14 of Arthrobacter sp. B7 (110 kDa, homodimer) [6], Planococcus sp. SOS Orange (150 kDa, homodimer) [17] and Arthrobacter sp. 32c (195 kDa, homotrimer) [9]. On the other hand,

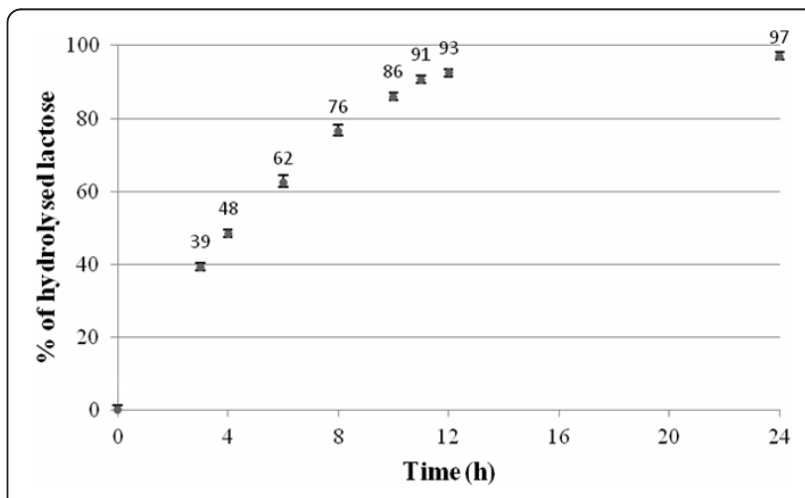

Figure 9 Hydrolysis of milk lactose by $1 \mathrm{U}$ of Paracoccus sp. $32 \mathrm{~d} \beta$-D-galactosidase as a function of time-course. 
Table 5 Kinetic parameters of Paracoccus sp. 32d $\beta$-D-galactosidase

\begin{tabular}{ccccc}
\hline Substrate & Temperature $\left({ }^{\circ} \mathbf{C}\right)$ & $\boldsymbol{K}_{\mathrm{m}}(\mathbf{m M})$ & $\boldsymbol{k}_{\text {cat }}\left(\mathbf{s}^{-\mathbf{1}}\right)$ & $\boldsymbol{k}_{\text {cat }} / \boldsymbol{K}_{\mathbf{m}}\left(\mathbf{s}^{-1} \mathbf{m M}^{-1}\right)$ \\
\hline ONPG & 10 & $1.17 \pm 0.11$ & $71.81 \pm 2.11$ & 61.38 \\
& 20 & $1.18 \pm 0.06$ & $138.3 \pm 2.19$ & 117.20 \\
\hline Lactose & 30 & $0.99 \pm 0.13$ & $206.00 \pm 6.92$ & 208.08 \\
& 10 & $2.94 \pm 0.39$ & $43.23 \pm 1.13$ & 15.06 \\
& 20 & $1.16 \pm 0.98$ & $66.67 \pm 5.6$ & 57.47 \\
& 30 & $4.28 \pm 0.57$ & $140.00 \pm 4.64$ & 32.71 \\
\hline
\end{tabular}

Hildebrand et al. [9] suggest that the low molecular mass of native $\beta$-D-galactosidase is crucial to the effective extracellular production of heterologous protein in yeast Pichia pastoris. Comparison of the authors' previous results for the production of LacZ $(\sim 490 \mathrm{kDa}$, homotetramer) Pseudoalteromonas sp. 22b in E. coli [12], with the analogous production efficiency of BgaL revealed that the low molecular mass of Paracoccus sp. 32d $\beta$-D-galactosidase also seems to be crucial for the effective production of this protein in $E$. coli cells.

ONPG is the preferred chromogenic substrate for BgaL (Table 2). Of interest is the fact that the many of the well-characterized cold-active $\beta$-D-galactosidases, isolated from Pseudoalteromonas sp. 22b [11], Arthrobacter sp. 20B [2], Arthrobacter sp. 32c [9], Carnobacterium piscicola BA (BgaB)* [19] and Arthrobacter sp. B7 isozyme $12^{*}[5]$ and isozyme $14^{*}[6]$ preferred $p$ nitrophenyl- $\beta$-D-galactopyranoside (PNPG) as a substrate (the asterisk means that the selected studies presented data only for $p$-Nitrophenyl (NP)-linked substrates).

Paracoccus sp. 32d $\beta$-D-galactosidase has an optimum temperature of approximately $40^{\circ} \mathrm{C}$, and a low thermostability at over $30^{\circ} \mathrm{C}$, and is active at a $\mathrm{pH}$ range of 6.08.0 with an optimum activity at 7.5. The comparable enzymatic properties were encountered in the other well-characterized cold-active $\beta$-D-galactosidases such as LacZ Arthrobacter sp. C2-2 [3], Arthrobacter sp. B7 isozyme 15 [4], and LacZ Pseudoalteromonas sp. 22b [11]. However, the enzymatic activity of the Paracoccus sp. $32 \mathrm{~d} \beta$-D-galactosidase at a temperature of $10^{\circ} \mathrm{C}$ is no more than around $15 \%$ of its maximum activity at optimum temperature (Figure 5). This is the one of the lowest relative activities for $\beta$-D-galactosidase at $10^{\circ} \mathrm{C}$, as compared with the analogous enzymatic activities reported at this temperature for cold-active $\beta$-D-galactosidases such as LacZ Arthrobacter sp. C2-2 ( 20\%) [3], LacZ Pseudoalteromonas sp. TAE 79b ( 40\%) [15], BgaB Carnobacterium piscicola BA ( 25\%) [19], LacZ Arthrobacter sp. 20B ( 70\%) [2], LacZ Arthrobacter sp. SB ( 70\%) [7], LacZ Arthrobacter sp. C2-2 ( 25\%) [3], LacZ Arthrobacter psychrolactophilus strain F2 ( 100\%) [8] and LacZ Pseudoalteromonas sp. 22b ( 24\%) [11]. To the best of the authors' knowledge, the lowest enzymatic activity $(\sim 10 \%$ of its maximum activity at optimum temperature) for cold-active $\beta$-D-galactosidase at $10^{\circ} \mathrm{C}$ has been reported for the enzyme isolated from Flavobacterium sp. 4214 [10].

The study of the kinetic properties of BgaL against an ONPG and a lactose as substrates, revealed the different trends of changes in the relevant $k_{\mathrm{cat}} / K_{\mathrm{m}}$ and $K_{\mathrm{m}}$ values against these substrates at 10,20 and $30^{\circ} \mathrm{C}$, respectively (Table 5). The markedly higher affinity of the lactose to BgaL at $20^{\circ} \mathrm{C}\left(K_{\mathrm{m}}\right.$ value $)$ than at $10^{\circ} \mathrm{C}$ or $30^{\circ} \mathrm{C}$ indicate the molecular adaptation of the enzyme to effective catalysis $\left(k_{\mathrm{cat}} / K_{\mathrm{m}}\right.$ value) of this native substrate at the optimal temperature of growth for Paracoccus sp. 32d. In contrast, an enzymatic efficiency of BgaL against ONPG (synthetic analogous of lactose) was increasing constantly with an increasing temperature.

Generally, the enzymatic properties for BgaL seem to be somewhat removed from those of cold-active $\beta$-Dgalactosidase which are ideal for the removal of lactose from milk where activity at refrigerated temperatures is critical. One of the most notable features of the BgaL enzyme is the inhibition of its hydrolytic activity by galactose and glucose, and $\mathrm{Ca}^{2+}$ ions. What surprised the authors, however, was the high efficiency finding as regards the removal of lactose from milk by BgaL from Paracoccus sp. 32d (Figure 9), that was comparable with the analogous ones of cold-active $\beta$-D-galactosidases previously characterized by us and our former co-workers from IBT at the Technical University of Lodz $[2,9,11,12,24]$. It seems to be possible that the complex physicochemical properties of milk could have a positive effect on the enzymatic activity of Paracoccus sp. $32 \mathrm{~d} \beta$ $D$-galactosidase. For example, this study found the significant differences between the enzymatic activity of BgaL in the Tris- $\mathrm{HCl}$ buffer and the sodium phosphate buffer, respectively. The enzymatic activity of BgaL against ONPG as a substrate at the same $\mathrm{pH}$ and temperature was $47 \%$ higher in the sodium phosphate buffer than in the Tris-HCl buffer, respectively.

\section{Conclusions}

This study presents the purification and characterization of a new $\beta$-D-galactosidase from Paracoccus sp. 32d. From the sequence analyses it is obvious that the BgaL 
enzyme is a member of the Glycoside Hydrolase Family 2. However, the sequence analysis of the BgaL enzyme reveal the lack of the BGal_small_N domain previously found in other cold-active $\beta$-D-galactosidases belong to $\mathrm{GH} 2$ family. Both the relatively low molecular weight of the Paracoccus sp. 32d BgaL enzyme, the efficient production of its recombinant soluble and active form in $E$. coli cells, and the efficient hydrolysis of lactose in milk suggested that Paracoccus sp. $32 \mathrm{~d} \beta$-D-galactosidase exhibits potential for the development of a new industrial cold-active biocatalyst.

\section{Methods}

\section{Bacterial strains and cultivation conditions}

The Paracoccus strain 32d from the Department of Microbiology GUT (Gdansk, Poland) collection of Antarctic microorganisms was isolated from the soil sampled in the neighborhood of the Henryk Arctowski Polish Antarctic Station at King George Island (Southern Shetlands, $\left.62^{\circ} 10^{\prime} \mathrm{S}, 58^{\circ} 28^{\prime} \mathrm{W}\right)$. Strain $32 \mathrm{~d}$ was cultivated in a modified Luria-Bertani medium: LBS (10 g peptone $\mathrm{K}, 5 \mathrm{~g}$ yeast extract, and $10 \mathrm{~g}$ sea salt per $1 \mathrm{~L}$, $\mathrm{pH} 7.5)$ at $20^{\circ} \mathrm{C}$.

E. coli LMG 194 (F_LlacX74 galE galK thi rpsL $\triangle p h o A$ (PvuII) $\triangle$ ara714 leu::Tn10) cells were used for cloning and expression of the recombinant Paracoccus sp. 32d $\beta$-D-galactosidase. What was important to note is that due to the deletion of lac operon $(\Delta l a c X 74)$ the E. coli LMG 194 is lacZ deficient strain. E. coli strain was grown on LB medium ( $10 \mathrm{~g}$ peptone $\mathrm{K}, 5 \mathrm{~g}$ yeast extract, and $10 \mathrm{~g} \mathrm{NaCl}$ per $1 \mathrm{~L}, \mathrm{pH} 7.5$ ) or on LB medium solidified with bacteriological agar at $37^{\circ} \mathrm{C}$ (for cloning and expression experiments) and $30^{\circ} \mathrm{C}$ (for expression experiments).

\section{Characterization and identification of the strain $32 d$}

Growth properties were determined in LAS broth (10 g peptone $\mathrm{K}, 5 \mathrm{~g}$ yeast extract, $15 \mathrm{~g}$ bacteriological agar and $10 \mathrm{~g}$ sea salt per $1 \mathrm{~L}, \mathrm{pH} 7.5)$. The strain $32 \mathrm{~d}$ was tested by using minimal media containing $0.5 \%(\mathrm{w} / \mathrm{v})$ of the glucose, galactose and lactose as a sole carbon source. The proteolytic, lipolytic and amylolytic activities of the analyzed strain were examined at $20^{\circ} \mathrm{C}$, on plates holding nutrient agar, enriched with skimmed milk, tributyrin, and starch, respectively.

The genus of the strain $32 \mathrm{~d}$ was assessed on the basis of the $16 \mathrm{~S}$ rDNA gene sequence, amplified by PCR technique with primers fD1 and rP2 [11]. The 16S rDNA PCR product was sequenced using ABI $3730 \mathrm{xl} / \mathrm{ABI}$ 3700 sequencing technology (Genomed, Poland). The 16S rRNA gene sequence was compared with those from the Ribosomal Database Project and the NCBI database aligned using the MEGA $5.0 \mathrm{http}: / / \mathrm{www}$.megasoftware.net/.

\section{General DNA manipulations}

Restriction enzymes were purchased from Fermentas (Lithuania). The T4 DNA ligase was purchased from Epicentre (USA). Restriction enzymes and other DNAmodifying enzymes were used in accordance with the manufacturer's recommendations. The reagents for PCR were purchased from DNA-Gdańsk II (Poland). The kits for genomic DNA isolation (Genomic Mini) and plasmid DNA isolation (Plasmid Mini) were purchased from A\&A Biotechnology (Poland).

\section{Genomic DNA library construction and $\beta$-D-galactosidase gene identification}

The chromosomal DNA from Paracoccus sp. 32d cells was extracted using a Genomic Mini kit according to the protocol for gram-negative bacteria. The genomic DNA was digested using the BglII and SalI endonucleases, and the resultant DNA fragments were purified by isopropanol precipitation protocol http://www.uccs.edu/ rmelamed/ Lab/General\%20Procedures/EthanolPrecip.html. The purified DNA fragments were ligated with T4 DNA ligase into the corresponding sites of $\mathrm{pBAD} / \mathrm{Myc}$-His A (Invitrogen, USA). The ligated DNA was transformed into E. coli LMG 194 and clones were selected on Luria-Bertani agar plates supplemented with ampicillin $\left(0.1 \mathrm{mg} \mathrm{ml}^{-1}\right), \mathrm{X}$-Gal $(0.02$ $\left.\mathrm{mg} \mathrm{ml}^{-1}\right)$, and IPTG $\left(0.1 \mathrm{mg} \mathrm{ml}^{-1}\right)$. The ampicillin, IPTG and X-Gal were purchased from Sigma (USA). The plates were incubated at $30^{\circ} \mathrm{C}$ for $18 \mathrm{~h}$ and then transferred to $20^{\circ} \mathrm{C}$. After $4 \mathrm{~h}$ of incubation at $20^{\circ} \mathrm{C}$, the two recombinant colonies, producing $\beta$-D-galactosidase turned blue. Plasmid DNA from the positive transformants (blue colonies) was prepared using the Plasmid Mini kit (A\&A Biotechnology, Poland). Samples with plasmid DNA were digested with selected restriction enzymes (Fermentas, Lithuania) to create restriction maps of the constructs under examination. DNA inserts sequencing was performed using $A B I$ $3730 \mathrm{xl} / \mathrm{ABI} 3700$ sequencing technology (Genomed, Poland). Sequence similarity analyses were carried out using the Basic Local Alignment Search Tool program and on the server at National Centre of Biotechnology, USA http://www.ncbi.nih.gov/blast. Nucleotide and deduced amino acids sequence analyses were performed with VNTI advanced 10 (Invitrogen, USA). The ORFs search was performed with the ORF Finder program http://www. ncbi.nlm.nih.gov/gorf/gorf.html. The ORF corresponding to the $\beta$-D-galactosidase was named the $b g a L$ gene. BgaL protein sequence analysis and classification was conducted by means of the InterProScan software http://www.ebi.ac. uk/interpro/.

\section{Expression and purification of recombinant BgaL of Paracoccus sp. 32d}

The expression vector $\mathrm{pBAD} / \mathrm{Myc}-\mathrm{His} \mathrm{A}$ (Invitrogen, USA) was used for the expression of the bgaL gene of 
Paracoccus strain 32d in E. coli strain LMG 194. The bgaL gene was amplified using Forgal32d primer 5'AAATCATGAGGGTGACCCAGAAACTGAAC-

CATGGC-3' (containing the BspHI recognition site), and Revgal32d primer 5'-AAATGTCGACCTAGCCGACGGTGACCGTGGCC-3' (containing the SalI recognition site). The parts of the primer sequences given in boldface are complementary to the nucleotide sequences of the Paracoccus sp. 32d bgaL gene, while the recognition sites for the restriction endonucleases are underlined and were designed to facilitate cloning. The PCR fragment obtained was cloned into the NcoI and SalI sites of pBAD/Myc-His A under the $\mathrm{P}_{\mathrm{BAD}}$ promoter, yielding pBAD/LacZ32d. The resultant recombinant plasmid was transformed into a competent cells of E. coli strain LMG 194. The transformants were grown in an LB medium $(1 \mathrm{~L})$ containing ampicillin $(0.1 \mathrm{mg}$ $\mathrm{ml}^{-1}$ ), and shaken, at $37^{\circ} \mathrm{C}$ and $200 \mathrm{rpm}$, to an optical density of 0.5-0.55 measured at $600 \mathrm{~nm}$. The culture was then supplemented with L-arabinose $(0.2 \% \mathrm{w} / \mathrm{v})$ to induce the expression of the $b g a L$ gene and grown for 8 $\mathrm{h}$ at $30^{\circ} \mathrm{C}$. Next, the recombinant $E$. coli cells were harvested by centrifugation at $4600 \times g$ for $15 \mathrm{~min}$. The cell pellet was resuspended in $30 \mathrm{ml}$ of the A buffer $(0.02 \mathrm{M}$ sodium phosphate buffer, $\mathrm{pH} 6.3,0.1 \mathrm{M} \mathrm{NaCl}$ ), and then the cells were then disrupted by sonication, and chilled on ice. The cell debris was collected by centrifugation at $13,000 \times g$ for $20 \mathrm{~min}$ at $4^{\circ} \mathrm{C}$ and then the cell-free extract was applied onto Fractogel EMD DEAE column (Merck, Germany) previously equilibrated with the A buffer. An elution was carried out with a linear $\mathrm{NaCl}$ gradient $(0.05-0.6 \mathrm{M})$ in the $\mathrm{A}$ buffer, and with a flow rate of $1 \mathrm{ml} \mathrm{min}^{-1}$. Afterwards, the purified $\beta-D$ galactosidase-active fractions were combined and dialyzed to the A buffer and applied onto a Resource Q column (Merck, Germany) previously equilibrated with the A buffer. An elution was carried out with a linear $\mathrm{NaCl}$ gradient $(0.1-0.6 \mathrm{M})$ in the $\mathrm{A}$ buffer, and with a flow rate of $0.5 \mathrm{ml} \mathrm{min}^{-1}$. Finally, the $\beta$-D-galactosidaseactive fractions, eluted within the a range of 0.3-0.35 M $\mathrm{NaCl}$, were combined and dialyzed to the $\mathrm{C}$ buffer $(0.02$ $\mathrm{M}$ sodium phosphate buffer, $\mathrm{pH}$ 7.3).

\section{Estimation of molecular weight}

The purified enzyme was applied onto a Superdex 200 10/300 GL gel-filtration column (Amersham Bioscience) pre-equilibrated with $50 \mathrm{mM}$ sodium phosphate buffer, $150 \mathrm{mM} \mathrm{NaCl}$ (pH 7.0). Gel filtration was performed by means of high-performance liquid chromatography, with the same buffer as the eluent, and at a flow rate of 0.5 $\mathrm{ml} \mathrm{min}^{-1}$, and the elution patterns were compared with those of the standard proteins. The standard proteins used were thyroglobulin $\left(M_{\mathrm{r}}=669,000 \mathrm{Da}\right)$, apoferritin $\left(M_{\mathrm{r}}=440,000 \mathrm{Da}\right), \beta$-amylase $\left(M_{\mathrm{r}}=200,000 \mathrm{Da}\right)$, alcohol dehydrogenase $\left(M_{\mathrm{r}}=150,000 \mathrm{Da}\right)$, bovine serum albumin $\left(M_{\mathrm{r}}=66,000 \mathrm{Da}\right)$, and carbonic anhydrase $\left(M_{\mathrm{r}}\right.$ $=29,000 \mathrm{Da})$.

\section{Protein determination}

Protein concentration was determined in accordance with Bradford [25] using BSA (bovine serum albumin) as a standard. SDS-PAGE was carried out on slabs $(10 \times$ $5.5 \mathrm{~cm}$ ) of $12 \%$ polyacrylamide gel, in line with Laemmli's method [26]. The samples were denatured for 10 min at $95^{\circ} \mathrm{C}$ in the presence of $10 \%$ SDS and $0.5 \% 2$ mercaptoethanol.

\section{Enzyme characterization}

The thermodependency of the enzyme activity was determined by incubating $5 \mu \mathrm{l}$ of the purified BgaL enzyme $\left(0.12 \mathrm{mg} \mathrm{ml}^{-1}\right)$ in a $0.02 \mathrm{M}$ sodium phosphate buffer, pH 7.3, with $100 \mu \mathrm{l}$ of ONPG $(3 \mathrm{mM})$, for $2 \mathrm{~min}$ at temperatures ranging from 0 to $70^{\circ} \mathrm{C}$. Reactions halted by the addition of $100 \mu \mathrm{Na}_{2} \mathrm{CO}_{3}(1 \mathrm{M})$ and then hydrolysis of the $o$-nitrophenyl group was then detected at $405 \mathrm{~nm}$. The thermostability of the BgaL enzyme was determined by incubating it at $20,30,40$, and $50^{\circ} \mathrm{C}$, removing aliquots for up to $120 \mathrm{~min}$. The enzyme activity was assayed at $20^{\circ} \mathrm{C}$ in the same manner as used for the thermodependency of enzyme activity assays.

One unit (U) of the activity denoted $1 \mu \mathrm{mol}$ of $o$ nitrophenol liberated from the substrate (ONPG) in 1 min and under the standard reaction conditions. (20 $\mathrm{mM}$ sodium phosphate buffer $\mathrm{pH} 7.3$ and $20^{\circ} \mathrm{C}$ ).

The optimum $\mathrm{pH}$ was determined by assaying activity of the BgaL enzyme at a $10 \mathrm{mM}$ Britton-Robinson buffer, with $\mathrm{pH}$ values ranging from 3.0 to 11.0. Enzyme activity was measured at $20^{\circ} \mathrm{C}$ and as described above. The $\mathrm{pH}$ stability profiles for the enzyme activity of the BgaL was determined by an initial incubation of the enzyme for $2 \mathrm{~h}$, at $20^{\circ} \mathrm{C}$ and in $10 \mathrm{mM}$ Britton-Robinson buffer solutions ( $\mathrm{pH}$ 4.0-9.0), followed by determination of the activity under conditions described above.

Requirements for metal ions $(10 \mathrm{mM})$ and selected reagents: $10 \mathrm{mM}$ EDTA, $10 \mathrm{mM}$ DTT, $10 \mathrm{mM}$ glutathione (oxidized form), $10 \mathrm{mM}$ 2-mercaptoethanol and $10 \mathrm{mM}$ urea solutions, were determined under standard conditions.

The substrate specificity of BgaL enzyme was estimated using 12 chromogenic substrates: $o$-nitrophenyl$\beta$-D-galactopyranoside (ONPG), $p$-nitrophenyl- $\beta$-Dgalactopyranoside (PNPG), $p$-nitrophenyl- $\beta$-D-galacturonide, $p$-nitrophenyl- $\beta$-L-arabinopyranoside, $p$-nitrophenyl- $\beta$-D-cellobioside, $\quad p$-nitrophenyl- $\beta$-Dmannopyranoside, $p$-nitrophenyl- $\beta$-D-glucopyranoside, $p$-nitrophenyl- $\alpha$-D-galactopyranoside, $p$-nitrophenyl- $\beta$ $D$-fucopyranoside, $p$-nitrophenyl- $\beta$-D-xylopyranoside, and $p$-nitrophenyl- $\beta$-D-glucuronide each at a 
concentration of $5 \mathrm{mM}$. Activity was measured at $20^{\circ} \mathrm{C}$ and as described above.

The kinetic parameters of the freshly purified enzyme were determined at 10,20 and $30^{\circ} \mathrm{C}$, and the reaction rate with ONPG (1.0-5.0 mM) and lactose (1.0-5.0 mM) as substrates was determined, respectively. The lactose concentration after enzymatic reaction was determined using Liquick Cor-Glucose kit (Cormay) to measure the concentration of glucose released during lactose hydrolysis.

The efficiency of $1 \mathrm{U}$ of Paracoccus sp. 32d $\beta$-D-galactosidase, in the hydrolysis of the lactose in milk $(10 \mathrm{ml})$ at $10^{\circ} \mathrm{C}$ was monitored by means of HPLC analysis using Aminex HPX-87H column (Bio-Rad), $5 \mathrm{mM}$ $\mathrm{H}_{2} \mathrm{SO}_{4}$ as a mobile phase and Agilent 1200 Series Refractive Index Detector. 1\% solutions of glucose, galactose and lactose were used as standards.

All experiments (above-mentioned) were done in triplicate.

\section{Nucleotide sequences accession numbers}

The $16 \mathrm{~S}$ rDNA and $\beta$-D-galactosidase gene sequences reported in this work have been deposited in the GenBank database and assigned the Accession Nos. GU111730.1 and GU111731.1, respectively.

\section{List of abbreviations used}

aa: amino-acid residues; Cys: cysteine; GSSG: oxidized glutathione; GH2: glycoside hydrolase family 2; IBT: Institute of Technical Biochemistry; HPLC: high-performance liquid chromatography; IPTG: isopropyl $\beta$-D-1thiogalactopyranoside; ONPG: o-nitrophenyl- $\beta$-D-galactopyranoside; PNPG: $p$ nitrophenyl- $\beta$-D-galactopyranoside; X-Gal: 5-bromo-4-chloro-3-indolyl- $\beta$-Dgalactopyranoside.

\section{Author details \\ 'Department of Microbiology and Immunology, Faculty of Biology, University of Szczecin, Felczaka 3c, 71-412 Szczecin, Poland. ${ }^{2}$ Department of Microbiology, Gdańsk University of Technology, Narutowicza 11/12, 80-233 Gdańsk, Poland. ${ }^{3}$ Department of Pharmaceutical Technology and Biochemistry, Gdańsk University of Technology, Narutowicza 11/12, 80-233 Gdańsk, Poland.}

\section{Authors' contributions}

AWW performed the cloning experiments, protein expression and purification experiments, characterized the BgaL enzyme and was involved in drafting the manuscript, $\mathrm{HC}$ analyzed the data, drafted the manuscript and coordinated the study, MW assisted with the protein purification and participated in drafting the manuscript, KKT carried out the HPLC experiments, PH isolated Paracoccus sp. strain 32d, JK conceived and assisted in coordinating its realization. All the authors have read and have approved the final manuscript.

\section{Competing interests}

The authors declare that they have no competing interests.

Received: 22 September 2011 Accepted: 13 December 2011 Published: 13 December 2011

\section{References}

1. Nakagawa T, Fujimoto Y, Ikehata R, Miyaji T, Tomizuka N: Purification and molecular characterization of cold-active beta-galactosidase from Arthrobacter psychrolactophilus strain F2. Appl Microbiol Biotechnol 2006, 72:720-725.
2. Białkowska AM, Cieśliński H, Nowakowska KM, Kur J, Turkiewicz M: A new $\beta$ galactosidase with a low temperature optimum isolated from the Antarctic Arthrobacter sp. 20B: gene cloning, purification and characterization. Arch Microbiol 2009, 191:825-835.

3. Karasová-Lipovová P, Strnad H, Spiwok V, Malá S, Králová B, Russell NJ: The cloning, purification and characterisation of a cold-active $b$ galactosidase from the psychrotolerant Antarctic bacterium Arthrobacter sp. C2-2. Enzyme Microb Technol 2003, 33:836-844.

4. Trimbur DE, Gutshall KR, Prema P, Brenchley JE: Characterization of a psychrotrophic Arthrobacter gene and its cold-active beta-galactosidase. Appl Environ Microbiol 1994, 60:4544-4552.

5. Gutshall KR, Trimbur DE, Kasmir JJ, Brenchley JE: Analysis of a novel gene and beta-galactosidase isozyme from a psychrotrophic Arthrobacter isolate. J Bacteriol 1995, 177:1981-1988.

6. Gutshall K, Wang K, Brenchley JE: A novel Arthrobacter beta-galactosidase with homology to eucaryotic beta-galactosidases. J Bacteriol 1997, 179:3064-3067.

7. Coker JA, Sheridan PP, Loveland-Curtze J, Gutshall KR, Auman AJ, Brenchley JE: Biochemical characterization of a beta-galactosidase with a low temperature optimum obtained from an Antarctic Arthrobacter isolate. J Bacteriol 2003, 185:5473-5482.

8. Nakagawa T, Ikehata R, Myoda T, Miyaji T, Tomizuka N: Overexpression and functional analysis of cold-active $\beta$-galactosidase from Arthrobacter psychrolactophilus strain F2. Protein Expr Purif 2007, 54:295-299.

9. Hildebrandt P, Wanarska M, Kur J: A new cold-adapted beta-Dgalactosidase from the Antarctic Arthrobacter sp. 32c - gene cloning, overexpression, purification and properties. BMC Microbiol 2009, 27;9:151.

10. Sørensen HP, Porsgaard TK, Kahn RA, Stougaard P, Mortensen KK, Johnsen MG: Secreted $\beta$-galactosidase from Flavobacterium sp. isolated from low-temperature environment. Appl Microbiol Biotechnol 2006, 70:548-557.

11. Turkiewicz M, Kur J, Białkowska A, Cieśliński H, Kalinowska H, Bielecki S: Antarctic marine bacterium Pseudoalteromonas sp. 22b as a source of cold-adapted $\beta$-galactosidase. Biomol Eng 2003, 20:317-324.

12. Cieśliński H, Kur J, Białkowska A, Baran I, Makowski K, Turkiewicz M: Cloning, expression and purification of a recombinant cold-adapted $\beta$ galactosidase from antarctic bacterium Pseudoalteromonas sp. 22b. Prot Expr Purif 2003, 39:27-34

13. Makowski K, Białkowska A, Olczak J, Kur J, Turkiewicz M: Antarctic, coldadapted $\beta$-galactosidase of Pseudoalteromonas sp. 22b as an effective tool for alkyl galactopyranosides synthesis. Enzyme And Microbial Technol 2009, 44:59-64

14. Hoyoux A, Jennes I, Dubois P, Genicot S, Dubail F, Francois JM, Baise E, Feller G, Gerday C: Cold-adapted $\beta$-galactosidase from the antarctic psychrophile Pseudoalteromonas haloplanktis. Appl Environ Microbiol 2001, 67:1529-1535.

15. Fernandes S, Geueke B, Delgado O, Coleman J: $\beta$-galactosidase from a cold-adapted bacterium: purification, characterization and application for lactose hydrolysis. Appl Microbiol Biotechnol 2002, 58:313-321.

16. Liu WY, Shi YW, Wang XQ, Wang Y, Wei CQ, Lou K: Isolation and identification of a strain producing cold-adapted $\beta$-galactosidase, and purification and characterization of the enzyme. Czech J Food Sci 2005, 26:284-290.

17. Sheridan PP, Brenchley JE: Characterization of a salt-tolerant family $42 \beta$ galactosidase from a psychrophilic antarctic Planococcus isolate. Appl Environ Microbiol 2000, 66:2438-2444.

18. Hu JM, Li H, Cao LX, Wu PC, Zhang CT, Sang SL, Zhang XY, Chen MJ, Lu JQ, Liu YH: Molecular cloning and characterization of the gene encoding cold-active $\beta$-galactosidase from a psychrotrophic and halotolerant Planococcus sp. L4. J Agric Food Chem 2007, 55:2217-2224.

19. Coombs JM, Brenchley JE: Biochemical and phylogenetic analyses of cold-active $\beta$-galactosidase from the lactic acid bacterium Carnobacterium piscicola BA. Appl Environ Microbiol 1999, 65:5443-5450.

20. Nakagawa T, Ikehata R, Uchino M, Miyaji T, Takano K, Tomizuka N: Coldactive acide $\beta$-galactosidase activity of isolated psychrophilicbasidiomycetous yeast Guehomyces pullulans. Microbiol Res 2006, 161:75-79.

21. Wang Q, Li G, Yu SQ, Zhang CT, Liu YH: A novel metagenom-derived $\beta$ galactosidase: gene cloning, overexpression, purification and characterization. Appl Microbiol Biotechnol 2010, 88:155-165. 
22. Henrissat B, Davies G: Structural and sequence-based classification of glycoside hydrolases. Curr Opin Struct Biol 1997, 7:637-644.

23. Herrchen M, Legler G: Identification of an essential carboxylate group at the active site of lacZ beta-galactosidase from Escherichia coli. Eur $J$ Biochem 1984, 138:527-531.

24. Makowski K, Białkowska A, Szczesna-Antczak M, Kalinowska H, Kur J, Cieśliński H, Turkiewicz M: Immobilized preparation of cold-adapted and halotolerant Antarctic beta-galactosidase as a highly stable catalyst in lactose hydrolysis. FEMS Microbiol Ecol 2007, 59:535-542.

25. Bradford MM: A rapid and sensitive method for the quantitation of microgram quantities of protein utilizing the principle of protein-dye binding. Anal Biochem 1976, 72:248-254.

26. Laemmli UK: Cleavage of structural proteins during the assembly of the head of bacteriophage T4. Nature 1970, 227:680-685.

doi:10.1186/1475-2859-10-108

Cite this article as: Wierzbicka-Woś et al:: A novel cold-active $\beta$-D-

galactosidase from the Paracoccus sp. $32 \mathrm{~d}$ - gene cloning, purification and characterization. Microbial Cell Factories 2011 10:108.

\section{Submit your next manuscript to BioMed Central} and take full advantage of:

- Convenient online submission

- Thorough peer review

- No space constraints or color figure charges

- Immediate publication on acceptance

- Inclusion in PubMed, CAS, Scopus and Google Scholar

- Research which is freely available for redistribution

Submit your manuscript at www.biomedcentral.com/submit 